\section{Best Historical Materials 2015}

\section{RUSA CODES History Section Historical Materials Committee}

RUSA History Section Historical Materials Committee contributing members: Sue A. McFadden, Kathleen M. Monti, Alexa L. Pearce, and Matthew J. Wayman, editor and chair.
Each year, the RUSA/CODES History Section Historical Materials Committee selects an assortment of resources that reflect the best resources for historical research. The 2015 list follows. All resources received a final review on November 17, 2015.-Editor

NPSHistory, Harry A. Butowski and Randall D. Payne http://npshistory.com

The National Park Service Electronic Library at: http:// npshistory.com is a portal to National Park History and curates historical documents, videos, and other e-resources that inform visitors of a comprehensive view of the NPS (National Parks Service). The NPSHistory site was created by Dr. Harry A. Butowsky and Randall D. Payne. Dr. Butowsky retired from the National Park Service in June of 2012 where he managed the official NPS e-Library. The portal, while not the the official gov site, provides what the site creators describe as an "American history textbook" (http://npshistory .com/about_us.htm).

An example of historical context is shown when comparing NPSHistory.com to the official National Parks Service site at: www.nps.gov/index.htm. A look at park brochures demonstrates this context as the gov site provides current 2015-16 brochures for the park at Mesa Verde, while the http://npshistory.com/ provides historical brochures from 1912 through 1979 for Mesa Verde. Surprisingly, both documents come from the gov web content; but a search of the gov site does not identify the 1912 brochure in a keyword search. The value of the NPSHistory site is that it provides images and documents in a hierarchical, directory-file structure under the link "Digital Library" that is sub-divided by kind of documentation and includes: books, periodicals, brochures, and reports/studies. The brochures are further organized alphabetically by park title.

The associated Facebook community for NPSHistory. com began in 2014 and provides current and relevant park information to park volunteers, employees, and those with a passion for the National Parks.-Sue A. McFadden, Indiana University East, Richmond, Indiana

Digital Irish Famine Archive. Jason King.

http://faminearchive.nuigalway.ie

Arguably the worst famine to occur in 19th century Europe, the Irish Famine was also known as the Irish Potato Famine of 1845-1849. In the early 1840s, the potato was the staple diet of nearly half of Ireland's impoverished subsistence farmers. The Famine was set into motion by a 


\section{FROM COMMITTEES OF RUSA}

combination of unusual weather and a late potato blight that caused years of crop failure. Many people starved while others escaped this hardship by emigrating to the United States and Canada. Those who fled to Canada in 1847-48 often landed in Montreal, contracted typhus, and were cared for by the French-Canadian Grey Nuns of Montreal or Sisters of Charity. The Sisters of Providence and Father Patrick Dowd also worked in the city's typhus fever sheds, tending to the emigrants who were often widows and orphans. Many of these participants left accounts of their experiences in French. Now, thanks to the efforts of Dr. Jason King with the University of Limerick, the Moore Institute at the National University of Ireland in Galway, the Ireland's Great Hunger Institute at Quinnipiac University, the Irish National Famine Museum, the Montreal Irish Monument Park Foundation, the Ireland Park Foundation, the iNue Partnership, and the Irish Research Council, these accounts have been digitized, transcribed, and translated from French through the Digital Irish Famine Archive. The Archive is simple and easy to navigate. Its holdings have been divided into four sections, each containing the aforementioned accounts. Each section contains downloadable PDF's and summaries accompanied by images related to the tragedy. One section even contains a video of a 2013 documentary about the return of the descendants of emigrant orphan, Daniel Tighe, from Quebec to Strokestown, Canada. Overall, the Archive will be an excellent resource for high school and college students in need of primary and secondary sources about the efforts made to help the Famine's emigrants to Canada.-Kathleen M. Monti, Harrisburg Area Community College, Harrisburg, Pennsylvania

\section{Free People of Color in Louisiana, LSU Libraries} http://lib.lsu.edu/sites/all/files/sc/fpoc

Free People of Color in Louisiana is an NEH funded project that brings together disparate archival collections of personal and family papers, documenting the lives of people of African descent who were either born free or who escaped from slavery and lived freely in the United States, prior to 1865 . The source libraries and archives for this project include Louisiana State University (LSU) Libraries Special Collections, The Historical New Orleans Collection, the Louisiana Research Collection in Tulane University Special Collections, the Historical Center at the Louisiana State Museum, and the Louisiana Division of the New Orleans Public Library.

Significantly, the collaborative nature of this project has allowed its creators to reunite collections from the same families that were previously scattered across repositories. The site is designed to facilitate easy access to the original catalog records and finding aids for the collections from their source libraries and archives, while presenting the digitized documents together on one searchable platform. The full collection is annotated with a contextual historical essay, covering the various contexts in which free people of color lived in the Americas, dating back to 1492. Additionally, the essay offers specific discussion of circumstances in Louisiana during its colonial, territorial, antebellum, Civil War, and post-Civil War periods. The documents are all freely available on the LSU Libraries Special Collections website. They are viewable as high quality, full color scans which may be adjusted by size, printed, and downloaded. In addition to the personal and family papers, the project offers digitized public records of immense value to researchers of free people of color. These include multiple volumes of indenture and emancipation records, often featuring testimony about why an enslaved person could be considered to be deserving of freedom.

Free People of Color in Louisiana will enable researchers to access and disseminate understudied dimensions of the history of race and slavery in the United States. The project represents an ambitious collaboration among its contributing institutions and will be of remarkable value to legal, cultural, social, and political historians and scholars of the United States and of the Atlantic World more broadly.-Alexa L. Pearce, University of Michigan, Ann Arbor, Michigan

\section{Wooster Digital History Project, College of Wooster http://woosterhistory.org}

Presented by the College of Wooster in Wooster, Ohio, the Wooster Digital History Project combines resources from the college's own Special Collections, the Wayne County Historical Society, and the Wayne County Public Library to provide a variety of online resources on the town's history. Included are app-based walking tours, exhibits on topics such as settlement, agriculture, social movements, and civic development, and a town map with locations linked to pages on the site. The four tours can be viewed via either web or mobile sites. They generally contain text with directions and information about notable sites within the town, but some images are provided as well. Each exhibit links to a page with text description of that item, links to sections of that exhibit to the right, and often images relating to the exhibit. Some include audio or videos as well, with local historians providing further information. The "Links/Sources" page provides not only links to other relevant web sites on local history, but also a bibliography of print sources on Wooster history. This easily navigable, appealing site provides an excellent example of well-presented local history.-Matthew J. Wayman, Penn State Schuylkill, Schuylkill Haven, Pennsylvania 